Article

\title{
Impact of Superantigen-Producing Bacteria on T Cells from Tonsillar Hyperplasia
}

\author{
Fiona J Radcliff ${ }^{1, *} \mathbb{0}$, Sharon Waldvogel-Thurlow ${ }^{2}$, Fiona Clow ${ }^{1}$, Murali Mahadevan ${ }^{2}$, \\ James Johnston $^{2}$, Gen Li ${ }^{1}$, Thomas Proft ${ }^{1}$ D, Richard G Douglas ${ }^{2}$ and John D Fraser ${ }^{1}$ \\ 1 Department of Molecular Medicine and Pathology, University of Auckland, Auckland 1023, New Zealand \\ 2 Department of Surgery, University of Auckland, Auckland 1023, New Zealand \\ * Correspondence: f.radcliff@auckland.ac.nz; Tel.: +64-9923-6272
}

Received: 8 May 2019; Accepted: 24 June 2019; Published: 27 June 2019

\begin{abstract}
Staphylococcus aureus and Group A Streptococcus (GAS) are common occupants of the tonsils and many strains produce potent exotoxins (mitogens) that directly target $\mathrm{T}$ cells, which could be a driver for tonsillar hyperplasia. Tonsil tissues from 41 patients were tested for these bacteria in conjunction with profiling of B and T cells by flow cytometry. S. aureus and GAS were detected in tonsil tissue from $44 \%$ and $7 \%$, respectively, of patients by bacteriological culture; immuno-histology showed bacteria in close proximity to both B and T lymphocytes. The presence of tonsillar S. aureus did not alter $\mathrm{B}$ or $\mathrm{T}$ cell populations, whereas peripheral blood mucosal-associated invariant T (MAIT) cells were significantly increased in $S$. aureus culture positive individuals $(p<0.006)$. Alterations of tonsil CD4 ${ }^{+}$TCR V $\beta$ family members relative to peripheral blood were evident in 29 patients. Three patients had strong TCR V $\beta$ skewing indicative of recent exposure to superantigens, their tonsils contained mitogenic bacteria, and supernatants from these bacteria were used to partially recapitulate the skewing profile in vitro, supporting the notion that superantigens can target tonsillar $\mathrm{T}$ cells in situ. Tonsils are a reservoir for superantigen-producing bacteria with the capacity to alter the composition and function of key immune cells.
\end{abstract}

Keywords: superantigen; Staphylococcus aureus; Streptococcus pyogenes; Group A Streptococcus; TCR V $\beta$; mucosal-associated invariant $\mathrm{T}$ cells; recurrent tonsillitis; obstructive sleep apnea; tonsillar hyperplasia

\section{Introduction}

A diverse range of microbes encompassing both commensal and pathogenic organisms have been isolated from human tonsils. There is ongoing interest in the flora associated with these tissues because enlargement of the tonsils (tonsillar hyperplasia) is a common indication for surgery. The requirement for surgery can arise either due to tonsillar hyperplasia causing conditions such as obstructive sleep apnea (OSA) or from recurrent tonsillitis (RT), which is caused by repeated infections. A tonsillectomy is one of the most frequent surgical procedures performed on children, with a growing proportion now performed to treat sleep apnea disorders such as OSA [1]. There are significant direct medical costs as well as an indirect economic burden associated with tonsillar hyperplasia [2,3]. Healthcare expenditure for treatment of acute and chronic RT in pediatric patients from the United States was estimated to be in excess of US $\$ 1.355$ billion in 2015 [3]. Of particular concern is the high usage of antibiotics to treat these conditions.

Numerous microbial drivers encompassing viruses, bacteria, and fungi have been implicated in RT, with Group A Streptococci (GAS) considered to be the most common bacterial cause of RT in children [4]. Additional pathogenic microbes are commonly isolated from infected tonsils including Staphylococcus aureus, Hemophilus influenzae, and Streptococcus pneumoniae [5-7]. Some of these microbes are more frequently recovered from within tissue, rather than the tonsil surface, suggesting their role 
in tonsillar disease may be underestimated [5]. Both S. aureus and GAS can sequester in intracellular locations [8,9], or produce biofilms [10], which may allow these organisms to persist by limiting exposure to antibiotics and the host immune response.

S. aureus and GAS have a significant arsenal of virulence factors designed to disarm the host immune response and contribute to invasive disease [11,12]. Of particular interest in the context of tonsillar hyperplasia are superantigens (SAgs), potent exotoxins that cross-link $\mathrm{T}$ cells and antigen-presenting cells in a non-antigen restricted manner resulting in $\mathrm{T}$ cell activation, expansion, and inflammatory cytokine production $[13,14]$. Multiple serologically distinct SAgs have been identified from these bacteria, but possession of specific sag genes varies between isolates. Each SAg has specificity for one or more TCR V $\beta$ family members, resulting in selective expansion, deletion, or anergy of targeted TCR $\mathrm{V} \beta$ subsets [14]. SAgs are best known for their role in life-threatening conditions such as toxic shock syndrome but are also linked to the pathogenesis of chronic or recurring conditions [15]. Studies using humanized MHC class II transgenic mice suggest SAgs are important for persistent colonization of the nasopharynx [16-18] as well as contributing to the severity of systemic disease $[19,20]$.

Clinical studies have primarily focused on the impact of SAgs on the distribution of TCR V $\beta$ family members and this information has been used to link SAg exposure to a range of clinical conditions including chronic rhinosinusitis [21], atopic dermatitis [22,23], and recurrent tonsillitis [24]. However, there is mounting evidence that SAgs impact on additional cell populations either directly or as a down-stream consequence of T-cell targeting $[25,26]$. Notably, SAgs can target and disarm innate lymphoid cells such as invariant natural killer T ( $i \mathrm{NKT}$ ) cells [27] and mucosal-associated invariant $\mathrm{T}$ (MAIT) cells [28] by cross-linking TCR V $\beta$ on these cells with MHC class II on antigen-presenting cells (APCs). MAIT cells recognize selected microbial metabolites presented by major histocompatibility complex-related protein 1 (MR1) [29], including products from S. aureus [30,31] and GAS [32], forming a key component of the early response to these and other pathogenic microbes. Of direct relevance to studies of tonsillar disease, exposure of tonsillar cells to the common and potent Streptococcal pyogenic exotoxin $\mathrm{A}$ (SpeA) has been shown to have a negative impact on $\mathrm{T}$ follicular helper $(\mathrm{TfH})$ cell activation and B cell viability, leading to significantly reduced production of Ig [33]. An in-depth examination of GAS RT patients indicated that many of these individuals have an HLA-linked susceptibility to SpeA, culminating in reduced numbers of TfH cells, smaller germinal centers in the tonsils, and a reduced antibody response to SpeA when compared to a matched cohort of OSA patients [34].

We have previously shown that $S$. aureus is common in tonsillar tissue, many isolates have the capacity to produce potent SAgs, and that the presence of $S$. aureus is frequently associated with perturbed TCR V $\beta$ populations [24]. This study extends these observations in a new cohort of patients, using additional techniques to confirm the location of $S$. aureus or GAS within tonsil tissues and a comparison of matched tonsil and peripheral blood TCR V $\beta$ profiles to verify local skewing of $\mathrm{T}$ cells. This study confirms that SAgs interact with immune cells in the tonsils, which may contribute to persistence or susceptibility to infection with S. aureus or GAS.

\section{Results}

\subsection{Patient Demographics}

Specimens from 41 donors with a median age of four years were examined, incorporating 23 tonsils removed to treat RT and 18 to alleviate symptoms associated with tonsillar hyperplasia, primarily obstructive sleep apnea (Table 1). There were no significant differences in gender, age, tonsil weight, leucocyte counts, or aerobic bacterial burden between these two groups of patients (Table 1). Thirty-two $(78 \%)$ of patients took penicillin-based or broad-spectrum antibiotics in the three months leading up to surgery, $13(32 \%)$ less than one month prior to surgery, with similar usage observed between the two patient groups. 
Table 1. Patient information including tonsil weights, leucocyte counts, and bacterial load.

\begin{tabular}{cccc}
\hline $\begin{array}{c}\text { Parameter Median } \\
\text { (Range) }\end{array}$ & Recurrent Tonsillitis $(\mathbf{n}=\mathbf{2 3 )}$ & $\begin{array}{c}\text { Tonsillar Hyperplasia } \\
(\mathbf{n}=\mathbf{1 8})\end{array}$ & Combined $(\mathbf{n}=\mathbf{4 1})$ \\
\hline Male/Female & $12 / 11$ & $9 / 9$ & $21 / 20$ \\
Age (years) & $4(1-42)$ & $4(2-58)$ & $4(1-58)$ \\
Tonsil Weight $(\mathrm{g})$ & $5.42(2.31-16.24)$ & $5.92(4.37-8.87)$ & $5.74(2.31-16.24)$ \\
Tonsil leucocyte/g $\times 10^{6}$ & $193(60-363)$ & $264(109-410)$ & $223(60-410)$ \\
Tonsil CFU/g $\times 10^{6}$ & $0.99(0.055-4.5)$ & $1.3(0.08-5.46)$ & $1.16(0.055-5.46)$ \\
Swab CFU $\times 10^{6}$ & $1.4(0.01-2.3)$ & $0.99(0.11-2.1)$ & $1.1(0.01-2.3)$ \\
\hline
\end{tabular}

\subsection{Estimation of Bacterial Load}

High numbers of bacteria were detected in tonsillar tissue after aerobic culture, typically exceeding $10^{6} \mathrm{CFU} / \mathrm{g}$, irrespective of the reason for surgery (Table 1). S. aureus was cultured from homogenized tissue or from both tissue and a surface swab in 18 (44\%) of individuals, including 5 RT and 13 tonsillar hyperplasia patients (Table 2). The quantity of $S$. aureus enumerated by culture was variable, ranging from occasional colonies to near-pure cultures (median $=13 \times 10^{4} \mathrm{CFU} / \mathrm{g}$, range $=0.023-430 \times 10^{4} \mathrm{CFU} / \mathrm{g}$ ). S. pyogenes was isolated from three RT patients ( $7 \%$ ), two isolates were identified as emm 89 and one as $\mathrm{emm} 28$. Quantification of these isolates by culture was similarly variable, ranging from $0.35,55$, and $128 \times 10^{4} \mathrm{CFU} / \mathrm{g}$. Emm typing of putative GAS isolates identified Group G Streptococci (GGS) StG62647, StG245, and Stg6792 in tonsil tissue from four patients and Group C Streptococcus (GGS) (StC47A) in a single individual.

Table 2. Detection of S. aureus and Group A Streptococus (GAS) in tonsils from 41 patients by culture and immuno-histology.

\begin{tabular}{ccccccc}
\hline Pathogen & \multicolumn{2}{c}{ Culture } & \multicolumn{1}{c}{ Immuno-Histology } & Combined (\%) \\
\hline & Surface Only & Tissue Only & Surface \& Tissue & Total \\
\hline S. aureus & 0 & 8 & 10 & 18 & 15 & $25(61)$ \\
GAS & 0 & 2 & 1 & 3 & 3 & $3(7)$ \\
GGS $^{1}$ & 0 & 3 & 1 & 4 & n.d. & $4(10)$ \\
GCS $^{2}$ & 0 & 0 & 1 & 1 & n.d. & $1(2.5)$ \\
\hline \multicolumn{7}{c}{}
\end{tabular}

\subsection{Detection of S. aureus and GAS in Tonsil Tissue}

Tissue sections from all 41 patients were labelled with antibodies targeting S. aureus or GAS and examined by fluorescence microscopy. This approach detected $S$. aureus in 15 patients and GAS in 3 patients (Table 2). Detection of bacteria by immuno-histology ranged from very occasional colonies (Figure 1A), small localized groups of colonies (Figure 1B), through to substantial clusters of bacteria (Figure 1C). There were discrepancies between S. aureus culture versus immuno-histology results (Table 2). Eight individuals were positive for S. aureus by both methods, whereas combining data from both techniques indicated that $S$. aureus was more common in the tonsils ( 25 individuals, $61 \%$ ) than suggested by culture results alone. In line with this observation, scanning sequential sections through entire tonsils clearly demonstrates that bacteria are not evenly distributed throughout the tissue [35], highlighting the limitations of sampling small pieces from what can be sizeable tissues. GAS was detected in the three individuals that were culture positive for this bacterium (Figure 1D-F). 
A

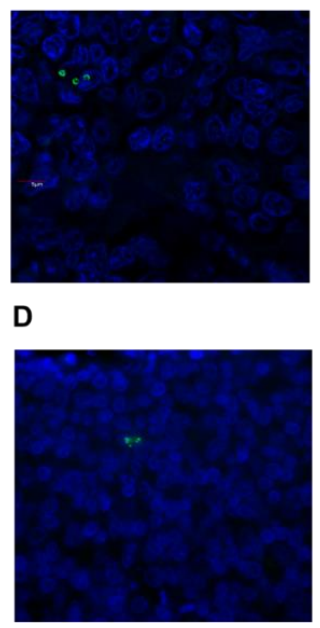

B

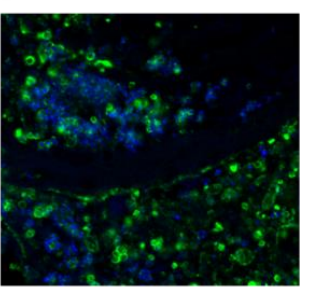

E

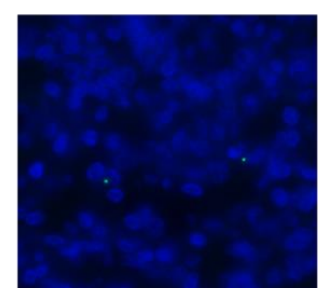

C

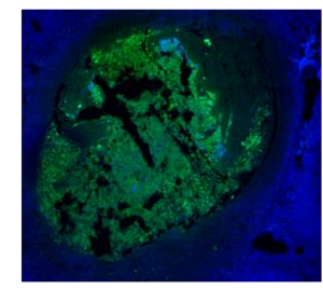

$\mathbf{F}$

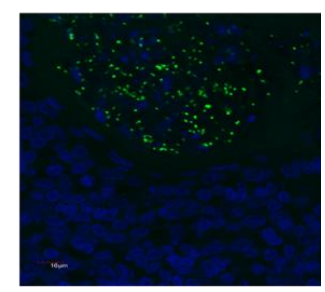

Figure 1. S. aureus and Group A Streptococcus (GAS) are located within tonsillar tissue. Bacteria were detected in paraffin-embedded tonsil tissue with antibodies specific for S. aureus or GAS (green), combined with a nuclear stain (DAPI, blue). Examples include S. aureus sparsely distributed in tonsillar tissue at $100 \times(\mathbf{A})$, clusters of bacteria at $100 \times(\mathbf{B})$ and at $10 \times(\mathbf{C})$; for GAS, occasional cocci are shown $(\mathbf{D}, \mathrm{E})$ and a large cluster of bacteria $(\mathbf{F})$, all at $100 \times$ magnification.

\subsection{Superantigen Profiling of Tonsillar S. aureus Isolates}

As S. aureus was common in tonsil tissues and was also cultured from 18 individuals, there were sufficient isolates available to determine the presence of sag genes and mitogenic activity. All isolates contained at least one sag gene but those containing selx (encoding staphylococcal enterotoxin-like toxin X) only were not mitogenic. Half of these isolates (9/18) were highly mitogenic (defined as ++ or +++ in proliferation assays) and contained one or more genes encoding for staphylococcal enterotoxins, typically seb, sec, or seg (Figure 2). All three GAS isolates were mitogenic in this assay (Table S1) and were tested for a limited panel of SAg (speA, speC, speG, and smeZ). The emm28 strain was both highly mitogenic (+++) and positive for speC, speG, and smeZ whereas speC was not amplified from the two emm89 isolates (mitogenicity $=++$ ).

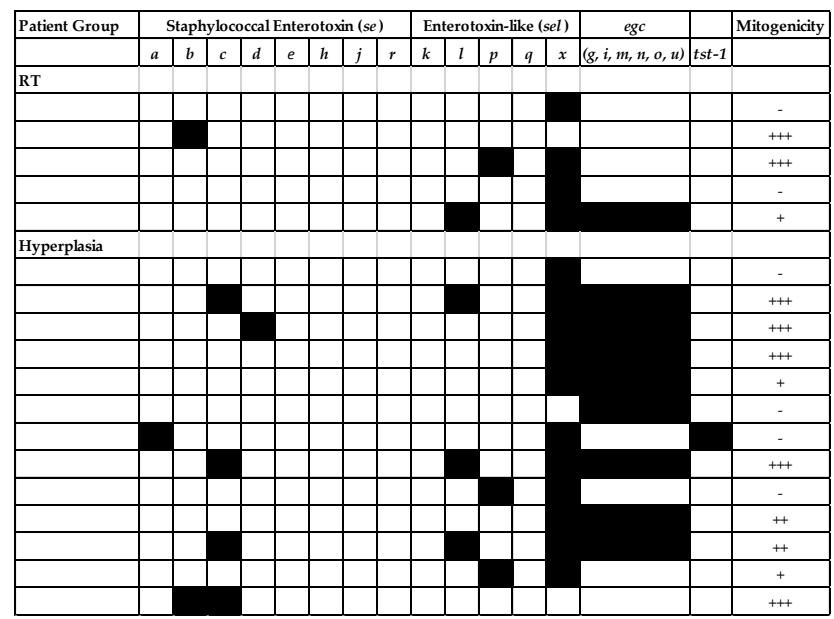

Figure 2. Presence of sag genes and mitogenicity of tonsil S. aureus isolates. A representative S. aureus isolate from each culture positive patient was tested for the presence of genes encoding for common Staphylococcal superantigens by multiplex PCR. Mitogenicity of supernatants from each of these isolates was determined using peripheral blood leucocytes (PBL) from three healthy donors and assigned a grade, with +++ being highly mitogenic. S. aureus from 5 recurrent tonsillitis (RT) and 13 hyperplasia patients were profiled; each line is a representative isolate from an individual patient. 


\subsection{Potential for S. aureus to Interact with Immune Cells}

Three-color fluorescent antibody labeling was used to determine whether S. aureus was present in close proximity to immune cells in situ. An initial examination of hematoxylin- and eosin-stained tissue sections indicated that inflammatory cells, particularly neutrophils, were rare in tonsil tissues and not present in the vicinity of bacteria. In all instances, $S$. aureus was found in close proximity to $\mathrm{CD}^{+} \mathrm{T}$ cells and $\mathrm{CD}_{20}{ }^{+} \mathrm{B}$ cells in the tonsil tissue (Figure 3A). GAS was also located within clusters of B and T cells (Figure 3B). It has been reported that S. aureus may sequester in an intracellular location [9], therefore sites where $S$. aureus appeared to be closely associated with immune cells were closely examined by confocal microscopy but this approach showed no conclusive evidence of intracellular localization of S. aureus.

A

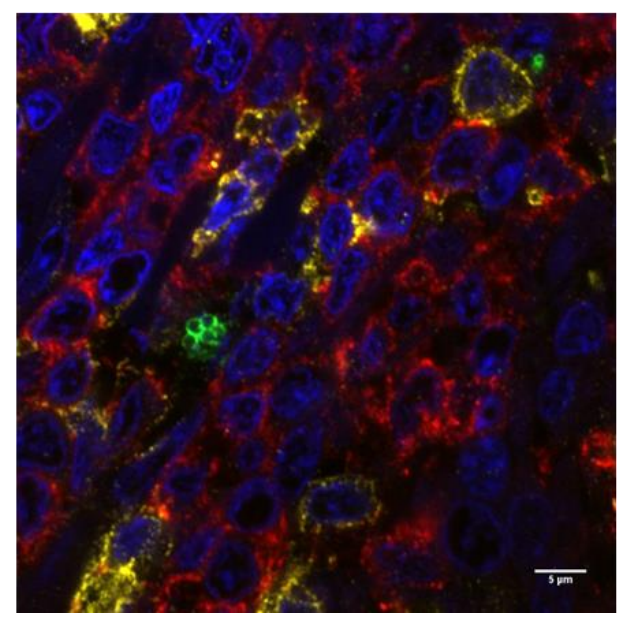

\section{B}

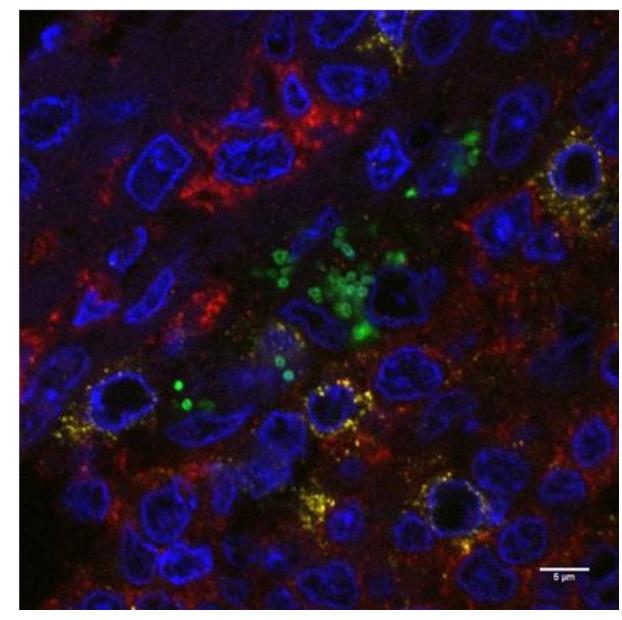

Figure 3. S. aureus and GAS are located in close proximity to B and T cells in the tonsils. Clusters of S. aureus (A) or GAS (B) detected by immuno-labelling and confocal microscopy in paraffin-embedded tonsillar tissue. Green $=$ S. aureus or GAS; blue $=\mathrm{DAPI}$; yellow $=\mathrm{CD}^{+} \mathrm{T}$ cells; red $=\mathrm{CD} 20^{+} \mathrm{B}$ cells . $100 \times$ magnification.

\subsection{Influence of S. aureus on Major Immune Cell Populations}

S. aureus is common in tonsil tissue and closely associated with immune leucocytes, therefore potential differences in major immune cell subsets were examined by comparing the proportion of $\mathrm{CD}^{+}, \mathrm{CD}^{+}, \mathrm{CD}^{+} \mathrm{T}$ cells, or $\mathrm{CD} 19^{+} \mathrm{B}$ cells in tonsils and blood from patients that were culture positive or negative for tonsillar $S$. aureus. There were no significant differences in the proportion of these cell subsets in either the tonsils or peripheral blood in the presence of S. aureus (Supplemental materials, Figure S1). Similarly, the $\mathrm{CD}^{+} \mathrm{CD}^{+} \mathrm{T}$ helper population had no changes in frequency of IL-2 receptor (CD25) or CXCR5 (TfH marker) expression (Supplemental materials, Figure S1). There were also no significant differences between OSA and RT patients (Supplemental materials, Figure S2).

The possible impact of local exposure to $S$. aureus on $\mathrm{CD} 3^{+} \mathrm{CD} 161^{++} \mathrm{V} \alpha 7.2^{+}$mucosal-associated invariant T (MAIT) cells, which directly respond to metabolites produced by S. aureus [30] and are in return targeted by bacterial superantigens [28], was examined by flow cytometry (Figure 4A). It was noted that peripheral blood MAIT cells were predominantly CD8 ${ }^{+}$whereas tonsil tissue contained roughly equivalent proportions of $\mathrm{CD}^{+}$and $\mathrm{CD}^{+}$MAITs (Figure $4 \mathrm{~B}$ ). The median percentage of MAIT cells was increased in peripheral blood (3.8\% vs. $2.0 \%, p=0.006)$ and tonsil tissue $(0.83 \%$ vs. $0.46 \%, \mathrm{~ns})$ of $S$. aureus culture positive individuals (Figure 4C). Tonsillar MAIT cells were highly activated, with a median of $89 \%$ positive for the late activation marker CD69 compared to $20 \%$ of MAIT cells in blood, but $S$. aureus status had no impact on expression of CD69 in either tissue (Figure 4D). MAIT cells were significantly activated compared with non-MAIT cells from the same tissue $(p<0.0001)$ (Figure 4D). 
A common target of Staphylococcal and Streptococcal SAg, TCR V $\beta 2$, is enriched in the MAIT cell population [36-38] therefore we determined the proportion of these cells in blood and tonsil tissue; TCR V $\beta 13.1$ was also detected in these cells as a non-targeted control. The proportion of TCR V $\beta 2^{+}$ MAITs was comparable in both tissues (median $=16 \%$ ), unaffected by the presence of $S$. aureus and significantly elevated compared to non-MAIT T cells (median $=6 \%, p<0.0001$ ) (Figure 4E). There was no difference in the proportion of TCR V $\beta 13.1^{+}$MAITs relative to non-MAITs (median $=2-3 \%$ ) and the proportion of TCR V $\beta 13.1^{+}$MAITs was unchanged by $S$. aureus in either tissue (Figure $4 \mathrm{~F}$ ). A comparison of MAIT cells in RT or OSA patients indicated that tonsillar MAIT cells were significantly reduced in RT patients (median of $0.46 \%$ vs. $0.955 \%, p=0.0306$; Supplemental materials, Figure S3A) but no significant differences in activation status, TCR V $\beta 2$ or TCR V $\beta 13.1$ frequency, were detected (Supplemental materials, Figure S3B-D).
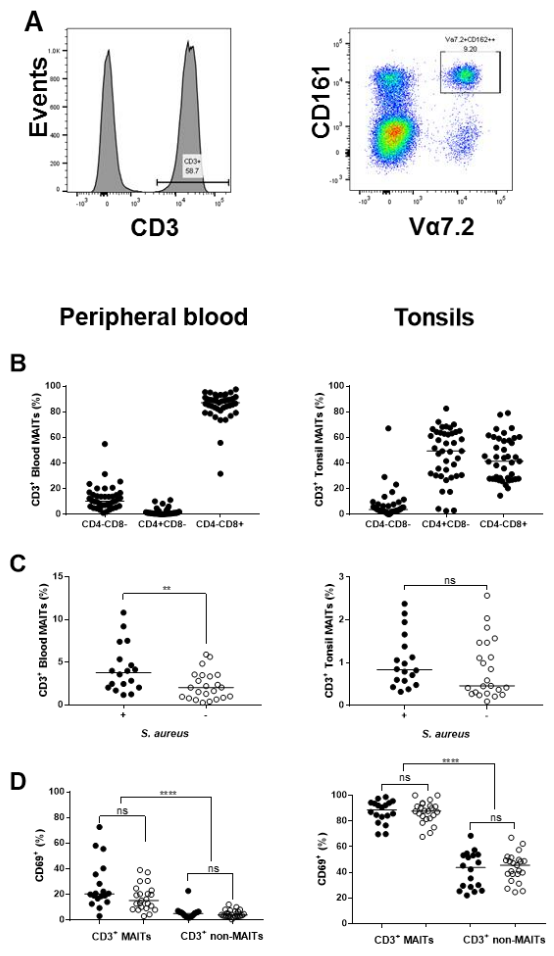

E
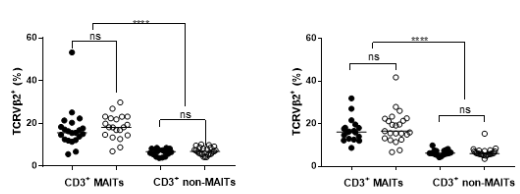

F
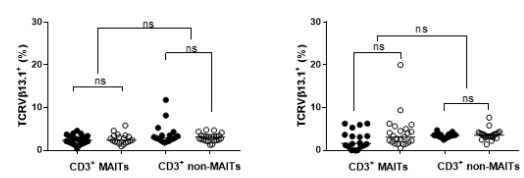

Figure 4. Characterization of mucosal-associated invariant T (MAIT) cells and the effect of S. aureus in the tonsils. A comparison of $\mathrm{CD}^{+}$MAIT and non-MAIT cells in blood and tonsil tissue in patients identified as culture positive (filled circle) or negative (open circle) for $S$. aureus. MAIT cells were identified as $\mathrm{CD}^{+} \mathrm{CD} 161^{++} \mathrm{V} \alpha 7.2^{+}(\mathrm{A})$ and the remaining $\mathrm{CD}^{+}$population classified as non-MAIT cells. These cell populations were quantified in blood or tonsil tissue (B) and then assessed for CD4 and CD8 (C), CD69 (D), TCR V 32 (E), and TCR V 13.1 (F). Values are expressed as a percentage of $\mathrm{CD}^{+}$cells. Each point is a value from an individual patient and the horizontal line is the median. The two patient groups were compared with a two-tailed Mann-Whitney test or a Kruskal-Wallis test with Dunn's multiple comparison test applied. 


\subsection{Assessment of TCR V $\beta$ Profiles in Tonsils and Peripheral Blood}

Tonsil TCR V $\beta$ profiles were determined for all patients and skewing of TCR V $\beta$ family members determined in comparison to reference values. Tonsil $\mathrm{CD} 4^{+}$and/or $\mathrm{CD} 8^{+} \mathrm{TCR} \mathrm{V} \beta$ populations were skewed in 27 (65\%) of participants, including 10 S. aureus-positive, 3 GAS-positive, and 11 S. aureus/ GAS-negative individuals, with no association to RT or hyperplasia (Supplemental materials, Table S1). Skewing was more commonly detected in $\mathrm{CD}^{+} \mathrm{T}$ cells than $\mathrm{CD}^{+} \mathrm{T}$ cells. A significant increase in the proportion of both $\mathrm{CD}^{+}$and $\mathrm{CD} 8^{+} \mathrm{T}$ cells from the same TCR V $\beta$ subset, which is more likely to be indicative of strong perturbation of TCR V $\beta$ family members, was detected in only three individuals: An RT patient with GAS (emm28) and skewing of TCR V $\beta 2$; another RT patient with skewing of TCR V $\beta 12$; and a tonsillar hyperplasia patient with S. aureus and skewing of TCR V $\beta 13.2$ (Supplemental materials, Table S1).

Tonsil TCR V $\beta$ values were normalized to peripheral blood leucocytes (PBL) to confirm that the TCR V $\beta$ skewing observed was localized to the tonsil tissue and not due to individual variability in distribution of TCR V $\beta$ family members. Data from all individuals were first combined to ascertain whether there were any consistent alterations in tonsil $\mathrm{CD} 4^{+}$or $\mathrm{CD} 8^{+} \mathrm{TCR} \mathrm{V} \beta$ profiles relative to peripheral blood. Most CD4 ${ }^{+}$TCR V $\beta$ family members had comparable values $(1.0+/-0.2)$ to peripheral blood, but a small number of family members had mean values outside this range including V 35.3 (1.3), 7.2 (1.29), 14 (0.78), and 20 (0.763) (Figure 5A). Nine CD8 ${ }^{+}$TCR V $\beta$ family members had mean values $\geq 1.2$ relative to peripheral blood, including V $\beta 5.3$ (1.52) and 7.2 (1.29) (Figure 5B) and none had mean values $\leq 0.8$. Due to the variability of the $\mathrm{CD} 8^{+}$profiles, further analysis focused on $\mathrm{CD}^{+} \mathrm{TCR} \mathrm{V} \beta$ profiles. A cut-off of \pm 0.5 was selected as the threshold for skewing of CD4 ${ }^{+} \mathrm{TCR}$ $\mathrm{V} \beta$ family members in individual patients. This analysis indicated that $29(71 \%)$ individuals had an altered distribution of tonsil CD4 ${ }^{+} \mathrm{TCR} V \beta$ cells relative to peripheral blood (Table S1) and was more common in patients with RT (20/23) than those with hyperplasia (10/18) but was not associated with the presence of S. aureus.

A

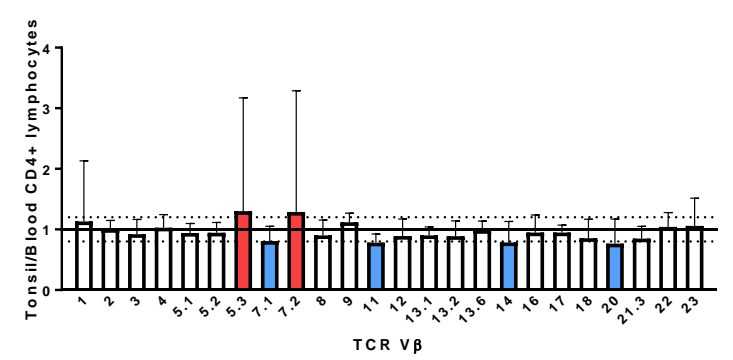

B

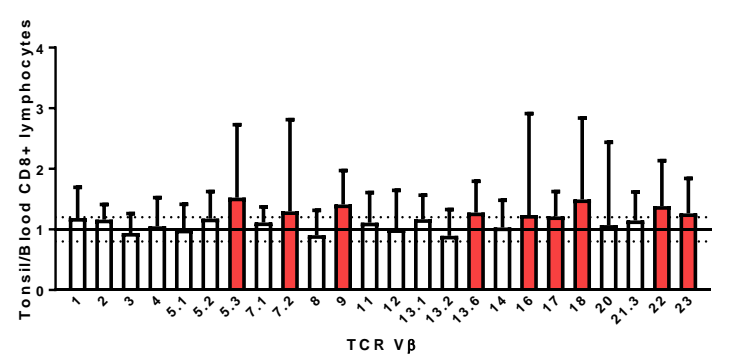

Figure 5. Tonsil TCR V $\beta$ profiles normalized to peripheral blood for all patients in the study. Tonsil TCR V $\beta$ profiles were normalized to peripheral blood profiles and data from all 41 patients combined to highlight any consistent differences for both $\mathrm{CD}^{+}(\mathbf{A})$ and $\mathrm{CD} 8^{+}(\mathbf{B}) \mathrm{T}$ cells; family members with a mean value of $\geq 1.2$ are highlighted in red, those with a mean value of $\leq 0.8$ are highlighted in blue. Data are mean + standard deviation.

The most striking examples of skewing were from three RT patients with altered distributions of selected $\mathrm{CD} 4^{+}$TCR V $\beta$ family members relative to both peripheral blood (Figure $6 \mathrm{~A}-\mathrm{C}$ ) and reference values (Supplemental materials, Table S1). Culture supernatants from the bacteria isolated from these patients were used to stimulate PBL to determine whether a comparable TCR V $\beta$ profile could be reproduced in vitro (Figure $6 \mathrm{~A}-\mathrm{C}$ ). A patient with mitogenic $S$. aureus containing sell, selx, and the egc genes had strong skewing of TCR V $35.3,7.1,9$, and 14 in tonsil tissue; these family members were also expanded in PBL exposed to supernatant from this S. aureus isolate (Figure 6A). The other individuals were culture positive for mitogenic GAS emm 28 and emm 89 isolates, with skewing of TCR V $\beta 2,4$, 8 (Figure $6 \mathrm{~B}$ ) or TCR Vß5.3, 7.2, and 16 respectively (Figure 6C). Supernatant from the GAS emm 28 
isolate stimulated selective expansion of TCR V $\beta 2$, 4, and 8 (Figure 6B) in healthy PBL, whereas the profile from the emm 89 strain showed less overlap, with expansion of TCR V $\beta 7.2$ but also TCR V $\beta 4$, 7.1, and 8 (Figure 6C).
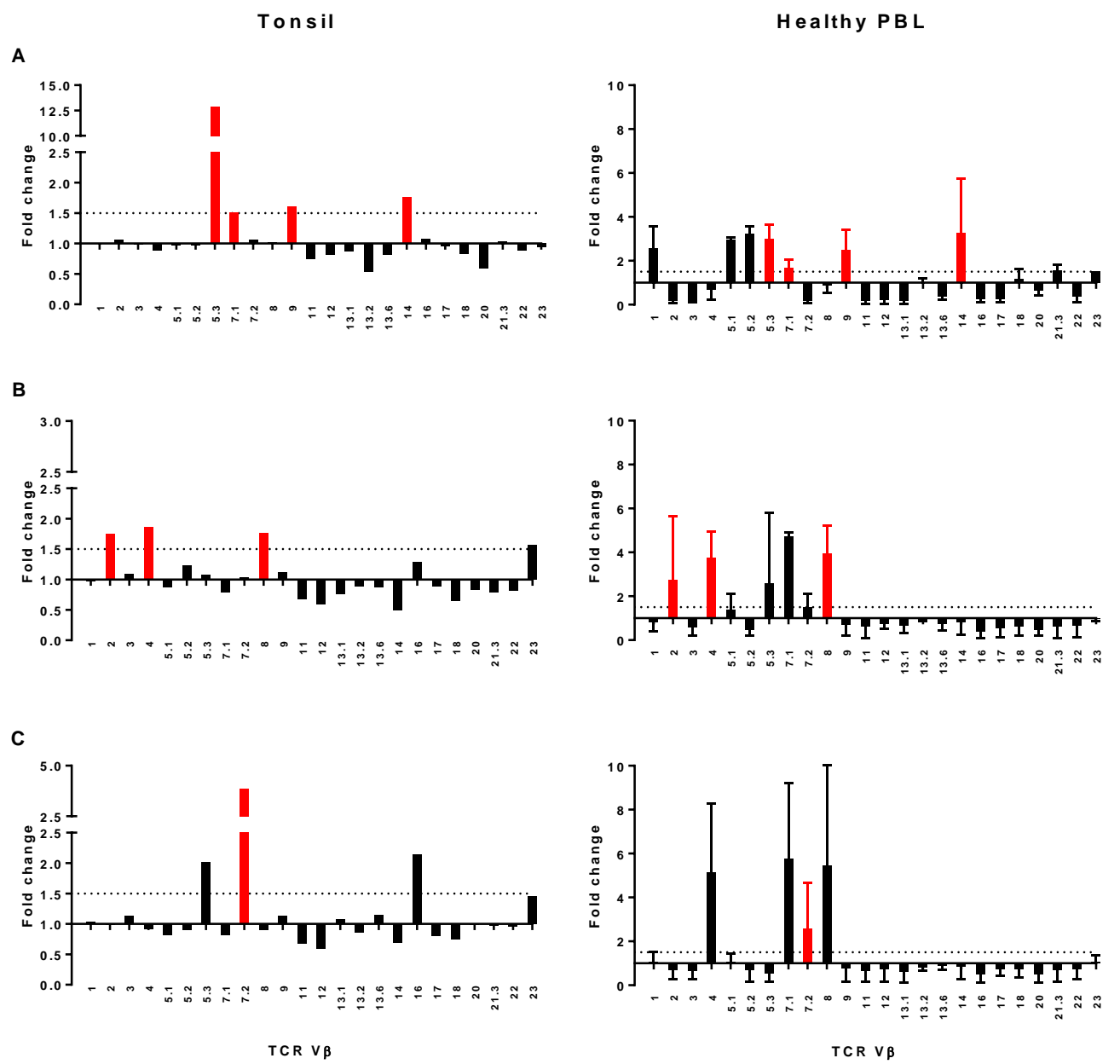

Figure 6. Comparison of TCR V $\beta$ profiles from tonsils and healthy PBL stimulated with bacterial supernatants. Individual profiles showing strong localized TCR V $\beta$ skewing in the tonsil (LHS) aligned with TCR V $\beta$ profiles of healthy PBL after stimulation with culture supernatant from $S$. aureus or GAS isolated from these individuals (RHS); red bars identify TCR V $\beta$ family members expanded in both sets of cells. Results are from three patients who underwent surgery to treat RT who were positive for S. aureus (A), GAS emm 28 (B), or GAS emm89 (C) respectively. Tonsil data are normalized to peripheral blood profiles from the same individual. PBL data are shown as fold change relative to unstimulated $\mathrm{PBL}$, incorporating mean values plus standard deviation from two healthy donors.

\section{Discussion}

This study builds on an earlier finding that skewing of TCR V $\beta$ subsets is relatively common in tonsillar tissue [24], demonstrating that selective expansion of TCR V $\beta$ populations is localized to the tonsils and that it is possible to partially reproduce patient TCR V $\beta$ profiles in vitro using supernatants from their own mitogenic $S$. aureus or GAS strains. Tonsillar hyperplasia is a multifactorial disease and there is now evidence to suggest that chronic exposure of immune cells to SAg producing bacteria may contribute to this condition, particularly RT, in a subset of patients.

Many of the S. aureus strains isolated from this patient cohort contained genes for potent SAgs and were highly mitogenic in in vitro assays. We previously found that patients with tonsillar S. aureus and RT were more likely to present with skewing of their tonsil TCR V $\beta$ subsets [24]. This association was not apparent in this set of patients and illustrates the challenges associated with obtaining conclusive 
evidence from a small cohort of individuals, with RT or OSA resulting from a variety of causes. Nonetheless, several RT patients had striking examples of skewed tonsillar CD4 ${ }^{+} \mathrm{TCR} V \beta$ family members relative to peripheral blood that were strongly suggestive of local SAg exposure. Supernatants from the patient's mitogenic $S$. aureus or GAS isolates drove selective expansion of some of these TCR V $\beta$ family members. An S. aureus isolate containing sell and sel $x$ genes and the enterotoxin gene cluster (egc) stimulated expansion of TCR V $\beta 5.3,7.1,9$, and 14 in both tonsil tissue and PBL, which is consistent with the activities of SAgs encoded by the egc [39]. An individual infected with a GAS emm28 strain positive for speC, speG, and smeZ had expansion of tonsillar CD4+ TCR V $\beta 2,4$, and $8 \mathrm{~T}$ cells suggestive of Streptococcal Mitogenic Exotoxin Z (SMEZ) [40,41]. A similar profile was produced in vitro after stimulation of PBL with supernatant from this isolate. Tonsil and PBL profiles from a patient carrying an speG+, smeZ+, and GAS emm 89 isolate were not as informative: the tonsil TCR V $\beta$ profiles (expansion of $\mathrm{V} \beta 5.3$ and 7.2) do not align with known $\mathrm{V} \beta$ targets of streptococcal SAgs [14]. In vitro stimulation of PBL with bacterial supernatant also showed stimulation of $V \beta$ 7.2, suggesting the presence of a secreted molecule capable of targeting this family member, but also expansion of V $\beta 4$ and 8 , which can be attributed to the presence of smeZ.

A global analysis of all patient tonsil CD4+ TCR V $\beta$ profiles demonstrated that expansion of TCR V $\beta 5.3$ and TCR V $\beta 7.2$ was most variable across this cohort and frequently expanded relative to PBL. These family members are not known targets of Streptococcal Sags [14], whereas TCR V $\beta 5.3$ is targeted by multiple Staphylococcal SAgs including members encoded in the egc frequently carried by S. aureus [42] as well as SEA, SED, and SEIL; and TCR V $\beta 7.2$ by SEA [39]. Conversely, a further four TCR $V \beta$ family members were under-represented in the tonsils, including additional targets of Staphylococcal SAgs: TCR V $\beta 7.1$ (SEIL), V $\beta 11$ (SER), V $\beta 14$ (SEB, SEC, SEG, SER, SEIU), and V $\beta 20$ (SEB, SEC) [14,39]. S. aureus with genes encoding for most of these sag genes were cultured from tonsil tissue and the egc was present in $50 \%$ of these isolates. These TCR V $\beta$ profiles are suggestive of local exposure to SAg commonly produced by $S$. aureus, however it is difficult to make a direct link between Sag-producing bacteria currently resident in the tonsils and alterations in TCR V $\beta$ populations. Exposure to SAg leaves a lingering footprint on the $\mathrm{T}$ cell repertoire and profiles may be attributable to past infections or exposure to multiple SAgs.

Acquiring stronger evidence of SAg activity in the tonsils is likely to require a combination of very careful selection of specific subsets of patients along with sophisticated immune profiling technologies. Specifically, data on patient HLA class II types could provide important linkages with SAg susceptibility, but collecting this information was beyond the scope of this study. A recent analysis of tissues from GAS RT patients has a compelling explanation as to why only a subset of the many individuals exposed to GAS actually go on to develop GAS RT. Tonsil tissues from GAS RT patients were observed to have a lower frequency of $\mathrm{TfH}$, smaller germinal centers, and a reduced circulating IgG response to SpeA, a common SAg produced by GAS [34]. Vulnerability to recurrent infections was then linked to an HLA class II-linked susceptibility to SpeA [34]. Direct exposure of tonsillar cells to SpeA has also revealed that SpeA targets TfH cells to impair B cell function, leading to a reduction in antibody production [33]. However, our study found no reduction of TfH in tonsils from RT patients, probably because our RT cohorts were not specifically selected for multiple episodes of GAS RT. CXCR5 was also the sole marker used to identify $\mathrm{CD}^{+} \mathrm{CD}^{+} \mathrm{TfH}$, rather than a more extended phenotyping panel. RT is a complex disease and a focus on links to other SAgs may reveal additional genetic susceptibilities and in vivo functions of these key virulence factors.

S. aureus is a frequent colonizer of tonsillar tissue and located in close proximity to key immune cells. Clusters of bacteria were ensconced within tonsil tissue with no evidence of phagocytic cells, such as neutrophils, in their vicinity. There was also no indication that $S$. aureus status impacted on the frequency or activation status of major $\mathrm{B}$ and $\mathrm{T}$ cell subsets in the tonsils. The possible in vivo consequences of $S$. aureus exposure on MAIT cells, a recently identified subset of T cells of particular interest in relation to both S. aureus and GAS, has not previously been determined. In our study, MAIT cells typically comprised $<1 \%$ of $\mathrm{CD}^{+} \mathrm{T}$ cells in the tonsils and were significantly activated 
compared to those in circulation, in line with previous reports on tissue resident MAIT cells from the liver [43] and the gut [44], suggesting the tonsils are a stimulatory environment for these cells. Blood and tonsillar MAITs were elevated in individuals that were culture positive for tonsillar S. aureus. In contrast, MAIT cells were significantly reduced in tonsil tissues, but not blood, from RT patients. Circulating MAIT cell populations initially decline, then rebound to elevated levels several weeks after a controlled acute infection with Salmonella paratyphi A [45], whereas the frequency of these cells is decreased in patients with severe sepsis [46] or in response to chronic bacterial infections [30,47,48]. Continuous exposure to selected bacterial metabolites may sustain a constant population of activated MAIT cells in the tonsils to maintain immune surveillance in the nasopharynx and peripheral sites. Conversely, it was recently demonstrated that MAIT cells are highly responsive to Staphylococcal Enterotoxin B (SEB), rapidly produce large quantities of pro-inflammatory cytokines, and become anergic [28]. Mitogenic isolates of S. aureus containing the genes for several potent SAgs including sea, seb, sec, and tst-1 are relatively common in the tonsils, both in this study cohort and a previous set of patients [24], suggesting the potential for MAIT cells to be exposed to and disarmed by locally produced SAgs. Selected TCR V $\beta$ family members are over-represented in MAIT cells including TCR $\mathrm{V} \beta 2$, which is targeted by several potent SAg from both S. aureus and GAS, including Toxic Shock Syndrome Toxin-1, SpeC, and SMEZ [14]. In our patient cohort, the proportion of TCR V $\beta 2^{+}$MAIT cells were not significantly different in the tonsils compared to peripheral blood of S. aureus-infected individuals, suggesting no targeted expansion or deletion of this cell type. It has been reported that TCR V $\beta 13.2^{+}$MAIT cells are highly susceptible to the effects of SEB, however this particular family member was not examined in our study. Production of SAgs may be an important mechanism used by both S. aureus and GAS to disable the local immune response and remain resident in mucosal tissues.

This study shows several strong examples of tonsillar TCR V $\beta$ skewing in conjunction with the presence of mitogenic strains of $S$. aureus or GAS capable of eliciting similar TCR V $\beta$ skewing profiles, suggesting that tonsil immune cells are exposed to these potent toxins. SAg may play a role in driving tonsillar hyperplasia in some individuals by disabling or subverting the local tonsil $\mathrm{T}$ cell response, including innate lymphoid cells such as MAIT cells, to facilitate ongoing susceptibility to infection. Both S. aureus and GAS were confirmed to be located within tonsil tissue in sites containing immune cells, therefore any SAgs produced by these bacteria are highly likely to encounter receptive populations of cells. However, in most instances, it was difficult to align the TCR V $\beta$ profiles detected in the tonsils with the SAg profile of the colonizing strain, if present. Addressing these issues will require testing the effect of multiple SAgs on human PBMC in vitro, ideally combined with humanized animal models to permit an in-depth examination of issues such as the impact of isolates expressing multiple potent SAgs on the TCR V $\beta$ repertoire, whether exposure to Sag-producing bacteria directly affects MAIT cell responses, and if prior exposure to a highly mitogenic isolate results in enhanced susceptibility to future infections. These approaches, combined with recent advances in immune cell phenotyping and genetic analyses, offer many opportunities to advance our knowledge of the drivers of tonsillar conditions.

At present, penicillin-based antibiotics are commonly prescribed for tonsillitis, which effectively targets GAS, but is unlikely to inhibit growth of S. aureus. Children with OSA are also regularly prescribed antibiotics and usage was comparable between the RT and OSA cohorts in this study. Inappropriate treatment with antibiotics risks the creation of new niches that permit overgrowth of S. aureus or other pathogens in this site, potentially exacerbating these conditions. Antibiotics are also likely to be only transiently effective in individuals with an HLA-linked susceptibility to recurrent GAS infection [34]. The drivers of tonsillar hyperplasia are multifactorial, but a better understanding of the role of SAg-producing bacteria in the tonsils may lead to improvements in non-surgical approaches for treating tonsillar hyperplasia, either in the form of a vaccine or application of more effective antibiotics. 


\section{Materials and Methods}

\subsection{Patients}

Tonsil tissue, a tonsil swab, and a blood sample were obtained from patients undergoing a routine tonsillectomy for RT or tonsillar hyperplasia at Gillies Hospital, Auckland, New Zealand. Approval to collect these specimens was gained from The University of Auckland Human Ethics Committee (ref: 010200). Written informed consent was acquired from the donors or their guardians prior to surgery. Patient age, gender, and the reason for surgery were collected and anonymized. Details of recent antibiotic usage was obtained and combined with specific prescribing information sourced from Auckland District Health Board databases.

\subsection{Bacteriology}

Tonsil specimens were sampled for bacterial growth, including detection of S. aureus and GAS as previously described [24]. Briefly, tissues were homogenized, duplicate samples cultured overnight at $37^{\circ} \mathrm{C}$ with/out $5 \% \mathrm{CO}_{2}$ on Columbia Blood Agar (CBA; Fort Richard, Auckland, New Zealand), and the total number of bacteria present after growth in aerobic conditions determined. Putative S. aureus colonies were cultured overnight on Mannitol Salt Agar (MSA; Fort Richard), and MSA positive colonies confirmed as $S$. aureus on the basis of catalase production and $S$. aureus-selective PCR $[24,49]$. GAS isolates were identified as $\beta$-hemolytic on CBA then confirmed using an established emm-typing PCR [50] and the product sequenced to identify the emm type.

\subsection{Histology}

Tissue pieces from both tonsils were placed in Carnoy's Fixative (60\% v/v Ethyl Alcohol, 30\% v/v Chloroform, $10 \% v / v$ Acetic Acid) for $\geq 24$ hours, embedded in paraffin and cut into $4 \mu \mathrm{m}$ sections. Sequential tissue sections were stained with hematoxylin and eosin to examine tissue architecture or antibody labelled for fluorescence microscopy. Tonsil sections were stained with antibodies to CD3, CD20, and S. aureus or GAS in conjunction with the nuclear marker DAPI (Invitrogen). The primary and secondary antibodies used are detailed in Table 3. Tissues were de-waxed followed by heat-induced epitope retrieval in the 2100 Retriever system (PickCell laboratories, Amsterdam, The Netherlands) in either $10 \mathrm{mM}$ citric acid, $\mathrm{pH} 6$ for detection of $S$. aureus, or EDTA-Tris buffer $(10 \mathrm{mM}$ Tris, $1.3 \mathrm{mM}$ EDTA, $\mathrm{pH}$ 8.5) for GAS. During the labelling process, the tissues were blocked in $10 \% v / v$ normal goat serum for 30 minutes; treated with antibodies diluted in Novocastra IHC diluent (Leica Biosystems, Wetzlar, Germany) added overnight at $5{ }^{\circ} \mathrm{C}$ (primary antibodies) or for 1 hour at room temperature (secondary antibodies); and washed in Tris buffered saline (24.8 $\mathrm{mM}$ Tris, $0.137 \mathrm{mM} \mathrm{NaCl}, 2.7 \mathrm{mM} \mathrm{KCl})$ between labelling steps. DAPI was included at a dilution of 1:10000 during the secondary antibody incubation step. Fully stained tissues were mounted in anti-fade mountant (Citifluor, Hatfield, PA, USA) and examined by fluorescence microscopy. Negative controls were included for every piece of tissue examined to verify specificity of the labeling. A positive control of tonsil containing either S. aureus or GAS was included with each batch of stains. Sections of both tonsils were screened for bacteria, with an average total area of $104.5 \mathrm{~mm}^{2}$ (range: $40.2-182 \mathrm{~mm}^{2}$ ) scanned for each patient. All tissue sections were screened for the presence of $S$. aureus or GAS, and images of bacteria from each positive individual were retained for confirmation by an experienced histologist (SW). Regions containing bacteria were assessed for the presence of $\mathrm{T}$ and $\mathrm{B}$ leucocytes across multiple patients and composite images were recorded. 
Table 3. Details of the antibodies used in this study.

\begin{tabular}{|c|c|c|c|c|}
\hline Specificity & Fluorochrome & Clone & $\begin{array}{c}\text { Quantity or } \\
\text { Dilution Used } \\
\end{array}$ & Source \\
\hline CD3 & Unconjugated $^{2}$ & Polyclonal (rabbit) & $1: 600$ & Cell Marque \\
\hline CD3 & Unconjugated $^{3}$ & F7.2.38 (mouse IgG1) & $1: 300$ & Dako \\
\hline CD3 & FITC $^{5,6,7}$ & UCHT1 & $2.5 \mu \mathrm{L}$ & BD Biosciences \\
\hline CD4 & APC-Cy7 $4,5,6$ & RPA-T4 & $2.5 \mu \mathrm{L}$ & BD Biosciences \\
\hline CD8 & AF- $647^{4,6}$ or BUV395 5 & RPA-T8 & $2.5 \mu \mathrm{L}$ & BD Biosciences \\
\hline CD19 & $\mathrm{PE}^{7}$ & HIB19 & $20 \mu \mathrm{L}$ & BD Biosciences \\
\hline CD20 & Unconjugated 2,3 & L26 (mouse IgG2a) & $1: 100$ & Leica \\
\hline CD21 & $\mathrm{APC}^{7}$ & B-ly4 & $5 \mu \mathrm{L}$ & BD Biosciences \\
\hline CD25 & $\mathrm{PE}^{6}$ & M-A251 & $20 \mu \mathrm{L}$ & BD Biosciences \\
\hline CD27 & PE-CF594 6,7 & M-T271 & $1 \mu \mathrm{L}$ & BD Biosciences \\
\hline CD69 & $P E^{5}$ & FN50 & $20 \mu \mathrm{L}$ & BD Biosciences \\
\hline CD161 & $\mathrm{APC}^{5}$ & DX12 & $20 \mu \mathrm{L}$ & BD Biosciences \\
\hline CXCR5 & AF- $647^{6}$ & RF8B2 & $1 \mu \mathrm{L}$ & BD Biosciences \\
\hline $\mathrm{V} \alpha 7.2$ & $\mathrm{Pe}-\mathrm{Cy} 7^{5}$ & $3 \mathrm{C} 10$ & $2.5 \mu \mathrm{L}$ & BioLegend \\
\hline $\mathrm{V} \beta 2$ & $P E^{5}$ & MPB2D5 & $20 \mu \mathrm{L}$ & Immunotech \\
\hline $\mathrm{V} \beta 13.1$ & $\mathrm{PE}^{5}$ & IMMU 222 & $20 \mu \mathrm{L}$ & Immunotech \\
\hline S. aureus & Unconjugated $^{2}$ & 11-248.2 (mouse IgM) & $1: 400$ & Merck, MAB930 \\
\hline S. pyogenes & Unconjugated $^{3}$ & Polyclonal (rabbit) & 1:7000 & Biorbyt orb99012 \\
\hline Mouse IgG1 & AF- $647^{3}$ & Polyclonal (goat) & $5 \mu \mathrm{g} / \mathrm{mL}$ & Thermo Fisher Scientific \\
\hline Mouse IgG2a & AF- $594^{2,3}$ & Polyclonal (goat) & $5 \mu \mathrm{g} / \mathrm{mL}$ & Thermo Fisher Scientific \\
\hline Mouse IgM & AF- $488^{2}$ & Polyclonal (goat) & $4 \mu \mathrm{g} / \mathrm{mL}$ & Thermo Fisher Scientific \\
\hline Rabbit IgG & AF- $488^{3}$ or AF- $647^{2}$ & Polyclonal (goat) & $4 \mu \mathrm{g} / \mathrm{mL}$ or $5 \mu \mathrm{g} / \mathrm{mL}$ & Thermo Fisher Scientific \\
\hline
\end{tabular}

\subsection{Superantigen Profiling}

All S. aureus isolates were sag profiled for Staphylococcal Enterotoxins (SE) and Staphylococcal Enterotoxin-like (SEl) genes including members of the enterotoxin gene cluster (egc) by multiplex PCR as previously described [24,51]. GAS isolates were processed as per the emm typing PCR and tested for the presence of speA, speC, speG, and smeZ using previously published primer sets and conditions [52]. Diluted supernatants from overnight cultures of all isolates were tested for mitogenicity on human peripheral blood leucocytes (PBL) from at least three healthy consenting donors [53]. Supernatants from GAS grown overnight in RPMI 1640 supplemented with 10\% v/v fetal bovine serum (Gibco by Life Technologies, Auckland, New Zealand) were also tested. PBL were cultured for 72 hours in the presence of serial 10 -fold dilutions of $S$. aureus or GAS supernatants with a starting dilution of 1:40, and proliferation quantified by measuring the uptake of $0.25 \mu \mathrm{Ci} /$ well [methyl ${ }^{3} \mathrm{H}$ ] thymidine (Perkin-Elmer, Waltham, MA, USA) during the final 6 hours of the incubation period. The degree of mitogenicity was defined as the reciprocal of the dilution that stimulated proliferation $>3$ times background. Supernatants that stimulated proliferation at a dilution of $\geq 400,000$ were recorded as ' +++ '; $4000-40,000$ as ' ++ '; $40-400$ as ' + '; and $\leq 40$ as ' - ' [24].

\subsection{Flow Cytometry}

Tonsil tissue was stored on wet ice in phosphate buffered saline (PBS) and transported to the laboratory for processing within 2 hours of surgery. Tonsil tissues were minced in PBS, further dissociated using a $70 \mu \mathrm{m}$ cell strainer, and leucocytes isolated by density gradient centrifugation over Ficoll-Hypaque ${ }^{\mathrm{TM}}$ PLUS (GE Healthcare, Uppsala, Sweden) [54]. Peripheral blood samples were collected into heparin tubes and diluted 1:1 in PBS prior to centrifugation over Ficoll-Hypaque at $400 \mathrm{~g}$ for 30 minutes. Isolated leucocytes were washed twice in PBS, enumerated using a hemocytometer, and up to $10^{6}$ cells/tube used for antibody labeling for flow cytometry. Cells were re-suspended and washed in FACS Buffer ( $2 \% v / v$ fetal bovine serum, $0.02 \% v / v$ sodium azide in PBS) for all subsequent steps then suspended in FACS Buffer supplemented with $0.5 \mu \mathrm{g} / \mathrm{mL}$ propidium iodide (Invitrogen, Eugene, OR, USA) for data acquisition. Specific antibody details and combinations are detailed in 
Table 3. Tonsil and peripheral blood leucocyte TCR V $\beta$ profiles were determined using antibodies to CD4 and CD8 in conjunction with the IOTest ${ }^{\circledR}$ Beta Mark TCR V $\beta$ Repertoire Kit (Immunotech, Marseille, France) as per the manufacturer's instructions. At least 5000 viable CD8 ${ }^{+}$(tonsil) or CD4+ (blood) events were collected per sample. Major leucocyte subsets $\left(\mathrm{CD}^{+}, \mathrm{CD}^{+}, \mathrm{CD} 8^{+}\right.$, and $\left.\mathrm{CD} 19^{+}\right)$ were identified by positive cell surface marker staining and expressed as a proportion of viable WBC. $\mathrm{CD}^{+} \mathrm{T}$ helper cell subsets were further characterized as $\mathrm{CD}^{+} \mathrm{CD}^{+} \mathrm{CD} 25^{+}$or $\mathrm{CD} 3^{+} \mathrm{CD} 4{ }^{+} \mathrm{CXCR} 5^{+}$ $\mathrm{TfH}[55,56]$. B cells were identified based on presence of CD19, with maturity and activation status determined with antibodies to CD21 and CD27, respectively. MAIT cells were identified as $\mathrm{CD}^{+}$ $\mathrm{CD} 161^{++} \mathrm{V} \alpha 7.2^{+}[57,58]$ with additional characterization using antibodies to CD4, CD8, CD69, TCR V $\beta 2$, or TCR V $\beta 13.1$. All flow cytometry data were acquired on a BD LSR II with FACS Diva Software v6.1.1 (BD Biosciences, Franklin Lakes, NJ, USA) and analyzed with FlowJo software v7.6.5 (Tree Star Inc, Ashland, OR, USA). Fluorescence-minus-one controls were used to determine placement of gates. Single, viable cells were selected on FSC/SSC profiles and the exclusion of PI. Proportionate representation of $\mathrm{CD} 4^{+}$or $\mathrm{CD} 8^{+} \mathrm{TCR} V \beta$ populations was determined and TCR V $\beta$ skewing defined as values $>$ two standard deviations above control values supplied with the TCR V $\beta$ repertoire kit [59]. Alternatively, tonsil TCR V $\beta$ values were normalized to blood TCR V $\beta$ values to examine possible differences between local versus peripheral TCR V $\beta$ profiles.

In-depth TCR V $\beta$ profiling was also conducted on PBL from two healthy donors after 6 days of in vitro stimulation with $1 \% v / v$ bacterial culture supernatant, with the addition of $50 \mathrm{IU} / \mathrm{mL}$ IL-2 (PeproTech Asia, Rehovot, Israel) after 72 hours [40]. Data are presented as the fold difference between PBL stimulated with bacterial culture supernatants and those in medium alone.

\subsection{Statistical Analyses}

Statistical analyses and plots were produced in Prism 7 (GraphPad Software, San Diego, CA, USA). Variables including tonsil weight, leucocyte count, and CFU of bacteria were compared for RT and OSA groups by Mann-Whitney test. The impact of S. aureus on major immune populations was analyzed by Mann-Whitney test or unpaired $t$-test for datasets containing non-parametric or parametric data, respectively. A comparison of characteristics of MAIT and non-MAIT CD3 ${ }^{+} \mathrm{T}$ cells were performed with a two-tailed Wilcoxon matched-pairs signed rank test. All plots include individual data points from each patient and the median value. A $p$ value of $<0.05$ was used as the cut-off for statistical significance.

Supplementary Materials: The following are available online at http://www.mdpi.com/2076-0817/8/3/90/s1, Figure S1: Presence of S. aureus in tonsil tissue does not alter major T and B cell subsets; Figure S2: Major T and B cell subsets are comparable in RT and OSA patients; Figure S3: Characterization of MAIT cells in RT and OSA patients; Table S1: TCR V $\beta$ profiles from tonsil $C D 4^{+}$or $C D 8^{+} \mathrm{T}$ cells of RT or OSA patients relative to healthy reference values or normalised against peripheral blood.

Author Contributions: Conceptualization, F.J.R., J.D.F., T.P., R.G.D.; methodology, F.J.R., F.C., S.W.-T.; validation, F.J.R., F.C.; formal analysis, F.J.R., F.C., S.W.-T., G.L., J.J.; resources, M.M.; data curation, F.J.R., F.C., S.W.-T.; writing-Original draft preparation, F.J.R.; writing-Review and editing, F.J.R., F.C., S.W.-T., J.J., G.L., M.M., R.D.G., T.P., J.D.F.; visualization, F.J.R., F.C., S.W.-T.; supervision, F.J.R., R.G.D., J.D.F.; project administration, F.J.R., F.C.; funding acquisition, F.J.R., R.G.D., J.D.F.

Funding: The School of Medicine Foundation, grant number 3712910; the Health Research Council of New Zealand grant number 12/1111; and a grant-in-aid from the Maurice and Phyllis Paykel Trust, grant number 3711140.

Acknowledgments: We thank Linley Lovich for coordinating the collection of tonsil tissue from Gillies Hospital and Stephen Edgar from the Flow Cytometry at the Faculty of Medical and Health Sciences, University of Auckland, for technical advice on the best combinations of dyes for flow cytometry.

Conflicts of Interest: The authors declare no conflict of interest. The funders had no role in the design of the study; in the collection, analyses, or interpretation of data; in the writing of the manuscript, or in the decision to publish the results. 


\section{References}

1. Gysin, C. Indications of pediatric tonsillectomy. ORL J. Otorhinolaryngol. Relat Spec. 2013, 75, 193-202. [CrossRef]

2. Dehlink, E.; Tan, H.L. Update on paediatric obstructive sleep apnoea. J. Thorac. Dis. 2016, 8, 224-235. [CrossRef] [PubMed]

3. Duarte, V.M.; McGrath, C.L.; Shapiro, N.L.; Bhattacharrya, N. Healthcare costs of acute and chronic tonsillar conditions in the pediatric population in the United States. Int. J. Pediatr. Otorhinolaryngol. 2015, 79, 921-925. [CrossRef] [PubMed]

4. Stelter, K. Tonsillitis and sore throat in children. GMS Curr. Top. Otorhinolaryngol. Head Neck Surg. 2014, 13, Doc07. [CrossRef] [PubMed]

5. Brook, I.; Yocum, P.; Shah, K. Surface vs. core-tonsillar aerobic and anaerobic flora in recurrent tonsillitis. JAMA 1980, 244, 1696-1698. [CrossRef] [PubMed]

6. DeDio, R.M.; Tom, L.W.; McGowan, K.L.; Wetmore, R.F.; Handler, S.D.; Potsic, W.P. Microbiology of the tonsils and adenoids in a pediatric population. Arch. Otolaryngol. Head Neck Surg. 1988, 114, 763-765. [CrossRef] [PubMed]

7. Jeong, J.H.; Lee, D.W.; Ryu, R.A.; Lee, Y.S.; Lee, S.H.; Kang, J.O.; Tae, K. Bacteriologic comparison of tonsil core in recurrent tonsillitis and tonsillar hypertrophy. Laryngoscope 2007, 117, 2146-2151. [CrossRef]

8. Stepinska, M.; Olszewska-Sosinska, O.; Lau-Dworak, M.; Zielnik-Jurkiewicz, B.; Trafny, E.A. Identification of intracellular bacteria in adenoid and tonsil tissue specimens: The efficiency of culture versus fluorescent in situ hybridization (FISH). Curr. Microbiol. 2014, 68, 21-29. [CrossRef]

9. Zautner, A.E.; Krause, M.; Stropahl, G.; Holtfreter, S.; Frickmann, H.; Maletzki, C.; Kreikemeyer, B.; Pau, H.W.; Podbielski, A. Intracellular persisting Staphylococcus aureus is the major pathogen in recurrent tonsillitis. PLoS ONE 2010, 5, e9452. [CrossRef]

10. Roberts, A.L.; Connolly, K.L.; Kirse, D.J.; Evans, A.K.; Poehling, K.A.; Peters, T.R.; Reid, S.D. Detection of group A Streptococcus in tonsils from pediatric patients reveals high rate of asymptomatic streptococcal carriage. BMC Pediatr. 2012, 12, 3. [CrossRef]

11. Thammavongsa, V.; Kim, H.K.; Missiakas, D.; Schneewind, O. Staphylococcal manipulation of host immune responses. Nat. Rev. Microbiol. 2015, 13, 529-543. [CrossRef] [PubMed]

12. Cole, J.N.; Barnett, T.C.; Nizet, V.; Walker, M.J. Molecular insight into invasive group A streptococcal disease. Nat. Rev. Microbiol. 2011, 9, 724-736. [CrossRef] [PubMed]

13. Xu, S.X.; McCormick, J.K. Staphylococcal superantigens in colonization and disease. Front. Cell. Infect. Microbiol. 2012, 2, 52. [CrossRef] [PubMed]

14. Langley, R.J.; Fraser, J.D.; Proft, T. Bacterial Superantigens and Superantigen-Like Toxins, 4th ed.; Elsevier: Amsterdam, The Netherlands, 2015.

15. Spaulding, A.R.; Salgado-Pabon, W.; Kohler, P.L.; Horswill, A.R.; Leung, D.Y.; Schlievert, P.M. Staphylococcal and streptococcal superantigen exotoxins. Clin. Microbiol. Rev. 2013, 26, 422-447. [CrossRef] [PubMed]

16. Xu, S.X.; Kasper, K.J.; Zeppa, J.J.; McCormick, J.K. Superantigens Modulate Bacterial Density during Staphylococcus aureus Nasal Colonization. Toxins 2015, 7, 1821-1836. [CrossRef] [PubMed]

17. Kasper, K.J.; Zeppa, J.J.; Wakabayashi, A.T.; Xu, S.X.; Mazzuca, D.M.; Welch, I.; Baroja, M.L.; Kotb, M.; Cairns, E.; Cleary, P.P.; et al. Bacterial superantigens promote acute nasopharyngeal infection by Streptococcus pyogenes in a human MHC Class II-dependent manner. PLoS Pathog. 2014, 10, e1004155. [CrossRef] [PubMed]

18. Zeppa, J.J.; Kasper, K.J.; Mohorovic, I.; Mazzuca, D.M.; Haeryfar, S.M.M.; McCormick, J.K. Nasopharyngeal infection by Streptococcus pyogenes requires superantigen-responsive Vbeta-specific T cells. Proc. Natl. Acad. Sci. USA 2017, 114, 10226-10231. [CrossRef] [PubMed]

19. Xu, S.X.; Gilmore, K.J.; Szabo, P.A.; Zeppa, J.J.; Baroja, M.L.; Haeryfar, S.M.; McCormick, J.K. Superantigens subvert the neutrophil response to promote abscess formation and enhance Staphylococcus aureus survival in vivo. Infect. Immun. 2014, 82, 3588-3598. [CrossRef] [PubMed]

20. Sriskandan, S.; Unnikrishnan, M.; Krausz, T.; Dewchand, H.; Van Noorden, S.; Cohen, J.; Altmann, D.M. Enhanced susceptibility to superantigen-associated streptococcal sepsis in human leukocyte antigen-DQ transgenic mice. J. Infect. Dis. 2001, 184, 166-173. [CrossRef]

21. Ou, J.; Wang, J.; Xu, Y.; Tao, Z.Z.; Kong, Y.G.; Chen, S.M.; Shi, W.D. Staphylococcus aureus superantigens are associated with chronic rhinosinusitis with nasal polyps: A meta-analysis. Eur. Arch. Otorhinolaryngol. 2014, 271, 2729-2736. [CrossRef] 
22. Leung, D.Y.; Gately, M.; Trumble, A.; Ferguson-Darnell, B.; Schlievert, P.M.; Picker, L.J. Bacterial superantigens induce $\mathrm{T}$ cell expression of the skin-selective homing receptor, the cutaneous lymphocyte-associated antigen, via stimulation of interleukin 12 production. J. Exp. Med. 1995, 181, 747-753. [CrossRef] [PubMed]

23. Lin, Y.T.; Wang, C.T.; Chao, P.S.; Lee, J.H.; Wang, L.C.; Yu, H.H.; Yang, Y.H.; Chiang, B.L. Skin-homing CD4 ${ }^{+}$ Foxp $^{+} \mathrm{T}$ cells exert Th2-like function after staphylococcal superantigen stimulation in atopic dermatitis patients. Clin. Exp. Allergy 2011, 41, 516-525. [CrossRef] [PubMed]

24. Radcliff, F.J.; Clow, F.; Mahadevan, M.; Johnston, J.; Proft, T.; Douglas, R.G.; Fraser, J.D. A potential role for staphylococcal and streptococcal superantigens in driving skewing of TCR V $\beta$ subsets in tonsillar hyperplasia. Med. Microbiol. Immunol. 2017, 206, 337-346. [CrossRef] [PubMed]

25. Stach, C.S.; Herrera, A.; Schlievert, P.M. Staphylococcal superantigens interact with multiple host receptors to cause serious diseases. Immunol. Res. 2014, 59, 177-181. [CrossRef] [PubMed]

26. Krakauer, T.; Pradhan, K.; Stiles, B.G. Staphylococcal Superantigens Spark Host-Mediated Danger Signals. Front. Immunol 2016, 7, 23. [CrossRef]

27. Hayworth, J.L.; Mazzuca, D.M.; Maleki Vareki, S.; Welch, I.; McCormick, J.K.; Haeryfar, S.M. CD1d-independent activation of mouse and human iNKT cells by bacterial superantigens. Immunol. Cell Biol. 2012, 90, 699-709. [CrossRef] [PubMed]

28. Shaler, C.R.; Choi, J.; Rudak, P.T.; Memarnejadian, A.; Szabo, P.A.; Tun-Abraham, M.E.; Rossjohn, J.; Corbett, A.J.; McCluskey, J.; McCormick, J.K.; et al. MAIT cells launch a rapid, robust and distinct hyperinflammatory response to bacterial superantigens and quickly acquire an anergic phenotype that impedes their cognate antimicrobial function: Defining a novel mechanism of superantigen-induced immunopathology and immunosuppression. PLoS Biol. 2017, 15, e2001930. [CrossRef]

29. Patel, O.; Kjer-Nielsen, L.; Le Nours, J.; Eckle, S.B.; Birkinshaw, R.; Beddoe, T.; Corbett, A.J.; Liu, L.; Miles, J.J.; Meehan, B.; et al. Recognition of vitamin B metabolites by mucosal-associated invariant T cells. Nat. Commun. 2013, 4, 2142. [CrossRef]

30. Le Bourhis, L.; Martin, E.; Peguillet, I.; Guihot, A.; Froux, N.; Core, M.; Levy, E.; Dusseaux, M.; Meyssonnier, V.; Premel, V.; et al. Antimicrobial activity of mucosal-associated invariant T cells. Nat. Immunol. 2010, 11, 701-708. [CrossRef]

31. Gold, M.C.; Cerri, S.; Smyk-Pearson, S.; Cansler, M.E.; Vogt, T.M.; Delepine, J.; Winata, E.; Swarbrick, G.M.; Chua, W.J.; Yu, Y.Y.; et al. Human mucosal associated invariant T cells detect bacterially infected cells. PLoS Biol. 2010, 8, e1000407. [CrossRef]

32. Meermeier, E.W.; Laugel, B.F.; Sewell, A.K.; Corbett, A.J.; Rossjohn, J.; McCluskey, J.; Harriff, M.J.; Franks, T.; Gold, M.C.; Lewinsohn, D.M. Human TRAV1-2-negative MR1-restricted T cells detect S. pyogenes and alternatives to MAIT riboflavin-based antigens. Nat. Commun. 2016, 7, 12506. [CrossRef] [PubMed]

33. Davies, F.J.; Olme, C.; Lynskey, N.N.; Turner, C.E.; Sriskandan, S. Streptococcal superantigen-induced expansion of human tonsil T cells leads to altered $\mathrm{T}$ follicular helper cell phenotype, B cell death, and reduced immunoglobulin release. Clin. Exp. Immunol. 2019, 197, 83-94. [CrossRef] [PubMed]

34. Dan, J.M.; Havenar-Daughton, C.; Kendric, K.; Al-Kolla, R.; Kaushik, K.; Rosales, S.L.; Anderson, E.L.; LaRock, C.N.; Vijayanand, P.; Seumois, G.; et al. Recurrent group A Streptococcus tonsillitis is an immunosusceptibility disease involving antibody deficiency and aberrant TFH cells. Sci. Transl. Med. 2019, 11. [CrossRef] [PubMed]

35. Johnston, J.; Hoggard, M.; Biswas, K.; Astudillo-Garcia, C.; Waldvogel-Thurlow, S.; Radcliff, F.J; Mahadevan, M.; Douglas, R.G. The bacterial community and local lymphocyte response are markedly different in patients with recurrent tonsillitis compared to obstructive sleep apnoea. Int. J. Pediatr. Otorhinolaryngol. 2018, 113, $281-288$. [CrossRef] [PubMed]

36. Tilloy, F.; Treiner, E.; Park, S.H.; Garcia, C.; Lemonnier, F.; de la Salle, H.; Bendelac, A.; Bonneville, M.; Lantz, O. An invariant T cell receptor alpha chain defines a novel TAP-independent major histocompatibility complex class Ib-restricted alpha/beta T cell subpopulation in mammals. J. Exp. Med. 1999, 189, 1907-1921. [CrossRef] [PubMed]

37. Lepore, M.; Kalinichenko, A.; Colone, A.; Paleja, B.; Singhal, A.; Tschumi, A.; Lee, B.; Poidinger, M.; Zolezzi, F.; Quagliata, L.; et al. Parallel T-cell cloning and deep sequencing of human MAIT cells reveal stable oligoclonal TCRbeta repertoire. Nat. Commun. 2014, 5, 3866. [CrossRef] [PubMed]

38. Reantragoon, R.; Corbett, A.J.; Sakala, I.G.; Gherardin, N.A.; Furness, J.B.; Chen, Z.; Eckle, S.B.; Uldrich, A.P.; Birkinshaw, R.W.; Patel, O.; et al. Antigen-loaded MR1 tetramers define T cell receptor heterogeneity in mucosal-associated invariant T cells. J. Exp. Med. 2013, 210, 2305-2320. [CrossRef] 
39. Thomas, D.; Dauwalder, O.; Brun, V.; Badiou, C.; Ferry, T.; Etienne, J.; Vandenesch, F.; Lina, G. Staphylococcus aureus superantigens elicit redundant and extensive human Vbeta patterns. Infect. Immun. 2009, 77, $2043-2050$. [CrossRef]

40. Unnikrishnan, M.; Altmann, D.M.; Proft, T.; Wahid, F.; Cohen, J.; Fraser, J.D.; Sriskandan, S. The bacterial superantigen streptococcal mitogenic exotoxin $\mathrm{Z}$ is the major immunoactive agent of Streptococcus pyogenes. J. Immunol. 2002, 169, 2561-2569. [CrossRef]

41. Proft, T.; Webb, P.D.; Handley, V.; Fraser, J.D. Two novel superantigens found in both group A and group C Streptococcus. Infect. Immun. 2003, 71, 1361-1369. [CrossRef]

42. Ferry, T.; Thomas, D.; Perpoint, T.; Lina, G.; Monneret, G.; Mohammedi, I.; Chidiac, C.; Peyramond, D.; Vandenesch, F.; Etienne, J. Analysis of superantigenic toxin Vbeta T-cell signatures produced during cases of staphylococcal toxic shock syndrome and septic shock. Clin. Microbiol. Infect. Off. Publ. Eur. Soc. Clin. Microbiol. Infect. Dis. 2008, 14, 546-554. [CrossRef]

43. Tang, X.Z.; Jo, J.; Tan, A.T.; Sandalova, E.; Chia, A.; Tan, K.C.; Lee, K.H.; Gehring, A.J.; De Libero, G.; Bertoletti, A. IL-7 licenses activation of human liver intrasinusoidal mucosal-associated invariant $\mathrm{T}$ cells. J. Immunol. 2013, 190, 3142-3152. [CrossRef] [PubMed]

44. Schmaler, M.; Colone, A.; Spagnuolo, J.; Zimmermann, M.; Lepore, M.; Kalinichenko, A.; Bhatia, S.; Cottier, F.; Rutishauser, T.; Pavelka, N.; et al. Modulation of bacterial metabolism by the microenvironment controls MAIT cell stimulation. Mucosal Immunol. 2018, 11, 1060-1070. [CrossRef] [PubMed]

45. Howson, L.J.; Napolitani, G.; Shepherd, D.; Ghadbane, H.; Kurupati, P.; Preciado-Llanes, L.; Rei, M.; Dobinson, H.C.; Gibani, M.M.; Teng, K.W.W.; et al. MAIT cell clonal expansion and TCR repertoire shaping in human volunteers challenged with Salmonella Paratyphi, A. Nat. Commun. 2018, 9, 253. [CrossRef] [PubMed]

46. Grimaldi, D.; Le Bourhis, L.; Sauneuf, B.; Dechartres, A.; Rousseau, C.; Ouaaz, F.; Milder, M.; Louis, D.; Chiche, J.D.; Mira, J.P.; et al. Specific MAIT cell behaviour among innate-like T lymphocytes in critically ill patients with severe infections. Intensive Care Med. 2014, 40, 192-201. [CrossRef] [PubMed]

47. Booth, J.S.; Salerno-Goncalves, R.; Blanchard, T.G.; Patil, S.A.; Kader, H.A.; Safta, A.M.; Morningstar, L.M.; Czinn, S.J.; Greenwald, B.D.; Sztein, M.B. Mucosal-Associated Invariant T Cells in the Human Gastric Mucosa and Blood: Role in Helicobacter pylori Infection. Front. Immunol. 2015, 6, 466. [CrossRef] [PubMed]

48. Leung, D.T.; Bhuiyan, T.R.; Nishat, N.S.; Hoq, M.R.; Aktar, A.; Rahman, M.A.; Uddin, T.; Khan, A.I.; Chowdhury, F.; Charles, R.C.; et al. Circulating mucosal associated invariant T cells are activated in Vibrio cholerae $\mathrm{O} 1$ infection and associated with lipopolysaccharide antibody responses. PLoS Negl. Trop. Dis. 2014, 8, e3076. [CrossRef]

49. Holtfreter, S.; Radcliff, F.J.; Grumann, D.; Read, H.; Johnson, S.; Monecke, S.; Ritchie, S.; Clow, F.; Goerke, C.; Broker, B.M.; et al. Characterization of a mouse-adapted Staphylococcus aureus strain. PLOS ONE 2013,8, e71142. [CrossRef]

50. Beall, B.; Facklam, R.; Thompson, T. Sequencing emm-specific PCR products for routine and accurate typing of group A streptococci. J. Clin. Microbiol. 1996, 34, 953-958.

51. Salgado-Pabon, W.; Case-Cook, L.C.; Schlievert, P.M. Molecular analysis of staphylococcal superantigens. Methods Mol. Biol. 2014, 1085, 169-185. [CrossRef]

52. Borek, A.L.; Obszanska, K.; Hryniewicz, W.; Sitkiewicz, I. Detection of Streptococcus pyogenes virulence factors by multiplex PCR. Virulence 2012, 3, 529-533. [CrossRef] [PubMed]

53. Holtfreter, S.; Bauer, K.; Thomas, D.; Feig, C.; Lorenz, V.; Roschack, K.; Friebe, E.; Selleng, K.; Lovenich, S.; Greve, T.; et al. Egc-Encoded superantigens from Staphylococcus aureus are neutralized by human sera much less efficiently than are classical staphylococcal enterotoxins or toxic shock syndrome toxin. Infect. Immun. 2004, 72, 4061-4071. [CrossRef] [PubMed]

54. Johnston, A.; Sigurdardottir, S.L.; Ryon, J.J. Isolation of mononuclear cells from tonsillar tissue. Curr. Protoc. Immunol. 2009, 7. [CrossRef]

55. Breitfeld, D.; Ohl, L.; Kremmer, E.; Ellwart, J.; Sallusto, F.; Lipp, M.; Forster, R. Follicular B helper T cells express CXC chemokine receptor 5, localize to B cell follicles, and support immunoglobulin production. J. Exp. Med. 2000, 192, 1545-1552. [CrossRef] [PubMed]

56. Schaerli, P.; Willimann, K.; Lang, A.B.; Lipp, M.; Loetscher, P.; Moser, B. CXC chemokine receptor 5 expression defines follicular homing T cells with B cell helper function. J. Exp. Med. 2000, 192, 1553-1562. [CrossRef] 
57. Dusseaux, M.; Martin, E.; Serriari, N.; Peguillet, I.; Premel, V.; Louis, D.; Milder, M.; Le Bourhis, L.; Soudais, C.; Treiner, E.; et al. Human MAIT cells are xenobiotic-resistant, tissue-targeted, CD161hi IL-17-secreting T cells. Blood 2011, 117, 1250-1259. [CrossRef]

58. Martin, E.; Treiner, E.; Duban, L.; Guerri, L.; Laude, H.; Toly, C.; Premel, V.; Devys, A.; Moura, I.C.; Tilloy, F.; et al. Stepwise development of MAIT cells in mouse and human. PLoS Biol. 2009, 7, e54. [CrossRef]

59. Conley, D.B.; Tripathi, A.; Seiberling, K.A.; Suh, L.A.; Harris, K.E.; Paniagua, M.C.; Grammer, L.C.; Kern, R.C. Superantigens and chronic rhinosinusitis II: Analysis of T-cell receptor V beta domains in nasal polyps. Am. J. Rhinol. 2006, 20, 451-455. [CrossRef]

(C) 2019 by the authors. Licensee MDPI, Basel, Switzerland. This article is an open access article distributed under the terms and conditions of the Creative Commons Attribution (CC BY) license (http://creativecommons.org/licenses/by/4.0/). 